\title{
An Empirical Analysis of Dynamic Competitiveness in Africa
}

\author{
Abdoulie Sireh-Jallow ${ }^{1} \&$ Demba $\mathrm{Ba}^{2}$ \\ ${ }^{1}$ Country Programs Department, IsDB. \\ ${ }^{2}$ Agriculture and Rural Development Department, IsDB.
}

\author{
Received: March 12, 2014 Accepted: April 4, 2014 Available online: May 2, 2014
}

doi:10.11114/aef.v1i1.369

URL: http://dx.doi.org/10.11114/aef.v1i1.369

\begin{abstract}
Specializing in the export of products made intensively from relatively abundant factors of production and in the import of those made from relatively scarce ones has had a lot of traction in international trade practice. Ample evidence, however, now shows that some nations are gaining a comparative advantage in new areas that they never had before. Consequently, the traditional policy option of many African countries of continuing to specialize in areas in which they already have a comparative advantage (such as exports of primary commodities) is complemented with that of moving to new areas (such as high technology manufacturing) in which they could gain some advantage even though they may not enjoy any at the moment. Trade strategies are therefore now being formulated specifically to transition economies from a state of non-competitiveness to a state of relative competitiveness. This transitioning is what we call dynamic competitiveness in this paper. Empirically, we determine this by analysing the growth of the World Economic Forum's Global Competitiveness Index of 27 African countries. This is complemented with the analysis of the growth of trade and transport costs using the World Bank Doing Business data. The study finds, among others, that even though the selected Sub-Saharan African countries are improving their (static) competitiveness over time, they cannot be said to be achieving dynamic competitiveness.
\end{abstract}

Keywords: dynamic comparative advantage, dynamic competitiveness, trade, empirical

\section{Introduction}

The competitiveness of nations continues to attract the attention of trade economists and policy makers alike. Specializing in the export of products made intensively from relatively abundant factors of production and in the import of those made from relatively scarce ones continues to have a lot of traction and still inspires the trade development practice. Ample evidence, however, now shows that some nations are gaining a comparative advantage in new areas that they never had before. South Korea's 15-year journey (Note i) in the 1960s from a state of non-competitiveness in manufacturing iron and steel products to one of competitiveness in exporting them cheaper than those of traditional exporters such as Japan and the United States of America is a case in point. So is the export of chocolate by Switzerland, which has no cocoa plantation. What Redding (1999) saw as a dilemma of many African countries (either to continue specializing in areas in which they already have a comparative advantage or to move to areas in which they have the potential to gain such an advantage) is no longer a dilemma as many African countries are now exploring both options. The trade strategies (Note ii) of many African countries are now being formulated specifically to transition their economies to a relative state of competitiveness which includes building capacities in new areas and deepening tradition ones. Nigeria targets, by 2020, a position among the top 100 in the World Economic Forum's (WEF) Global Competitiveness Index ( $\mathrm{GCI}$ ) ranking by deepening its specialization in the oil sectors but also diversifying the economy by redeveloping capacities in the non-oil sectors. In the 2013 Global Competitiveness Report, Nigeria is ranked 131 out of 185 countries.

The transitioning from a state of non-competitiveness to one of competitiveness is what we call dynamic competitiveness in this paper, drawing anchor from Redding (1999)'s theoretical framework of dynamic comparative advantage. It is defined using the growth of GCI of 27 African countries (Note iii) which is complemented with an analysis of the growth of production and trade costs in these countries based on the World Bank Doing Business dataset. The proxy for production costs is the sum of the cost of starting a business, the minimum paid-in capital required, the costs of securing construction permits and installing electricity, all measured as percentage of income per capita. The proxy for the cost of trade across borders is the sum of the cost of importing and exporting a container across borders. The growth trends of these indicate the dynamic competitiveness of the countries over time. 
The paper is divided into five sections including this introduction in Section I. Some definitions of competitiveness are presented in Section II and a definition of dynamic competitiveness along with the theoretical framework on which it is anchored, are presented in Section III. An empirical application of the theory is given in Section IV starting with a review of the static and dynamic competitiveness trends of the individual countries followed by a regional viewpoint. This is, however preceded by an analysis of the trade patterns of these countries from 2000 to 2012. The conclusion is given in Section V.

\section{Review of Definitions of Competitiveness}

Various definitions of competitiveness abound in the economic literature. Some authors and institutions have pinned it down to some workable index; however, others argue that the concept is difficult to gauge or even define by any single set of variables. However, a number of such indices are now annually produced by reputable organizations and extensively quoted by development practitioners and academics alike. They include the Global Competitiveness Index of the World Economic Forum and the Doing Business Index of the World Bank. All said, it is now generally agreed that competitiveness is complex and involves many dimensions that interact (Farrugia (2002)).

Porter (1990), one of the most respected personalities in this field, proposed the well-known "diamond approach", which illustrates the systemic relationship between four factors of competitiveness: factors and demand conditions (first and second), firm strategy and rivalry context (third) and supporting industries. Each point of the diamond affects the factors essential for achieving international competitiveness. Ul Haque, Bell, Dahlman, Lall, and Pavitt (1995) argue that a firm is considered competitive if it is able to sustain its earnings over time and can be viewed as a strong competitor if it is able to increase both its market share and its earnings. They contend that mastery of technology and the ability to effect and manage technological change are decisive in determining an economy's competitive strength. Ji and Seater (2010) found that in some cases, even where no technology transfer occurs, the effect of trade on a country's growth rate is the same if the country adopts its trading partners' research and development (R\&D) technology.

Odhiambo, Kristjanson, and Kashangaki (1996) compare domestic resource cost (Note iv) (DRC) of production with the official exchange rate. A commodity has a comparative advantage when, at the prevailing market prices, its DRC is equal to or less than the prevailing official exchange rate. From the perspective of the profitability of exports, Elbadawi (1998) constructed a real exchange rate (RER) based on a competitiveness index that accounts for the influences of RER misalignment and variability. The model yields equilibrium real exchange rate and misalignment variables, which are subsequently used in an export model as proxies of the profitability of the export sector.

It is generally agreed that a stable and an enabling macroeconomic environment is another factor crucial to the growth of an economy, in general, and exports, in particular (see Elbadawi 1998, Paredes 1988 and Rodrik 1994). A healthy and educated workforce is vital to a country's competitiveness and productivity and workers' skills have been found to be statistically significant in the competitiveness of a region's clothing and textile industry (see Woods \& Mayer 1998, and Biggs, Miller, Otto \& Tyler 1996, among others). Cockburn, Siggel, Coulibaly, and Vezina (1998) argue that the clearest evidence of a firm's international competitiveness is its profitability compared to that of international competitors. They define competitiveness as simply the capacity of firms to sell their products profitably by having a relatively lower unit cost of production than their competitors on the international market. In other words, to be competitive, a country's monetary unit cost should be lower than those of its competitors.

Using a general equilibrium model of endogenous growth, Redding (1999) investigates the dilemma of developing economies when it comes to specializing either in areas in which they already have a comparative advantage or in areas in which they have the potential to gain such an advantage even though they may not have at the moment. Building on the Ricardian theory of comparative advantage, he introduced the concept of dynamic comparative advantage, which is the basis for the dynamic competitiveness used in this paper. He illustrated that an economy is said to have a static comparative advantage in the low-tech sector at time $t$ if the opportunity cost of producing the low-tech good at home is lower than producing it in another economy. Based upon this illustration, he proposed a simple definition of dynamic comparative advantage concerned with changes in static competitiveness over time in relative levels of opportunity costs i.e. the dynamic analog of the traditional static definition. Thus, the home country is said to have a dynamic comparative advantage in low-tech production at time $t$ if the growth rate of the opportunity cost of producing the low-tech good at time $t$ is lower in the home country. We will revisit this concept since it provides the theoretical framework for dynamic competitiveness as used in this paper.

Over the years, multilateral organizations have also computed indices to enable them make cross country or regional comparisons. The American Commission on Industrial Competitiveness (ACIC) defined competitiveness as a country's ability to produce goods and services that meet the test of international markets and at the same time increase the real income of citizens (Tyson (1992), Ostry (1991)). The United Nations Conference on Trade and Development (UNCTAD) uses a concentration index for exports to compare competitiveness among countries; UNIDO uses a six-variable Competitive Industrial Performance Index (CIPI) dichotomized into transactional capacity and transformational capability (UNIDO 2009). 
The World Economic Forum (WEF) (2013) defines competitiveness as the set of institutions, policies and factors that determine the level of productivity of a country, which in turn, determines the level of prosperity that can be earned by an economy: more competitive economies tend to be able to produce higher levels of income for their citizens. WEF (2012) argues that each of its twelve pillars measures various aspects of competitiveness. The quality of institutions has a strong bearing on competitiveness and growth; however, an extensive and efficient infrastructure is crucial for the effective functioning of an economy. Furthermore, a well-developed transport and communications infrastructure network, uninterrupted electricity supply and a solid and extensive telecommunications network are also fundamental for the competitiveness of an economy. Macroeconomic stability is also considered a requirement for greater productivity since macroeconomic disarray harms an economy. WEF (2012) explains further that ultimately all the pillars in the competitiveness index measure the various ways business is done in a particular country: the cost of dealing with bureaucracy, the cost of having poor infrastructure, the cost of having an uneducated and unhealthy labour force, the cost of dealing with violence, the cost of hiring and firing workers, the cost of not having access to an efficient financial sector, the cost of not having suppliers or networks, the cost of not being able to rely on universities, the cost of not having the best available technology, etc. Thus, by reducing any of these costs, a government is able to improve its competitiveness.

In 2003, the World Bank published its first report on Doing Business. The Report now outlines 11 indicators (from 5 at the start) and ranks 185 economies (from 133). For each economy, the ranking is done with the use of the percentile rankings of each of 10 topics (Note v) (WB (2013)) and each indicator measures a different aspect of the business regulatory environment.

All the definitions above have attracted criticisms, which, in some cases, have helped to improve them. The GCI has improved so much in terms of both coverage and depth that what it measures now is completely different form it measured in the early 2000s. It is now more comprehensive since it combines both qualitative and quantitative dimensions. With respect to Doing Business, it was revised and an additional measure, distance to frontier, introduced in 2013 owing to criticisms of its limited scope. Where the Doing business ranking compares economies with one and other, the distance to frontier benchmarks economies to the frontier in regulatory practice by measuring the absolute distance to the best performance in each category (WB (2013)). These criticisms notwithstanding, computed indices make cross-country comparisons easier and have thus continued to enjoy traction.

\section{Defining Dynamic Competitiveness and Its Theoretical Framework}

The theoretical framework anchoring our definition of dynamic competitiveness is borrowed from Redding's (1999) notion of dynamic comparative advantage in which he theoretically argues that a home economy (h) is said to have a static comparative advantage in the low-tech sector at time $t$ if the opportunity cost of producing the low-tech good at home is lower than the one in another economy (z) i.e.

$$
\frac{A_{h}(t)}{A_{z}(t)}<\frac{A^{*}{ }_{h}(t)}{A^{*}(t)}
$$

Where $\mathrm{A}_{\mathrm{h}}(\mathrm{t}) / \mathrm{A}_{\mathrm{z}}(\mathrm{t})=$ opportunity cost of producing a low-tech product in a home country and $\mathrm{A}_{\mathrm{h}}(\mathrm{t}) / \mathrm{A}{ }_{\mathrm{z}}(\mathrm{t})=$ opportunity cost of producing a low-tech product in another country.

On the basis of this concept, he proposed a simple definition of dynamic comparative advantage that is concerned with changes in static competitiveness over time at relative levels of opportunity cost i.e. the dynamic analog of the traditional static definition. Thus, the home country is said to have a dynamic comparative advantage in low-tech production at time $t$ if the growth rate of the opportunity cost of producing the low-tech good at time $t$ is lower in the home country; that is to say the home country will have a dynamic comparative advantage in low-tech production if and only if

$$
\begin{aligned}
& \frac{\partial\left(A_{h}(t) / A_{z}(t)\right) / \partial t}{A_{h}(t) / A_{z}(t)}<\frac{\partial\left(A^{*}{ }_{h}(t) / A^{*}{ }_{z}(t)\right) / \partial t}{A_{h}(t) / A_{z}(t)} \\
\Leftrightarrow & \left(\frac{\dot{A_{h}(t)}}{A_{h}(t)}-\frac{\dot{A_{z}(t)}}{A_{z}(t)}\right)-\left(\frac{A^{*}{ }_{h}(t)}{A^{*}{ }_{h}(t)}-\frac{A^{*}{ }_{z}(t)}{A^{*}{ }_{z}(t)}\right)<0
\end{aligned}
$$

Extending this dynamic notion of comparative advantage to competitiveness, we define dynamic competitiveness as the growth rate of a country's static competitiveness (GCI in our case) overtime, in other words, Country A enjoys dynamic competitiveness over Country B if the growth rate of Country A's GCI is higher than that of Country B, i.e.,

$$
\frac{\dot{G()_{B}}}{g(t)_{B}}=\frac{\partial\left[G(t)_{B}\right]}{\partial \operatorname{tg}(t)_{B}}<\frac{\dot{G(t)} A}{g(t)_{A}}=\frac{\left.\partial[G M t)_{A}\right]}{\partial \operatorname{tg}(t)_{A}}
$$


Where $\mathrm{G}(\mathrm{t})_{\mathrm{B}} / \mathrm{g}(\mathrm{t})_{\mathrm{B}}=$ growth rate of the GCI of Country B at time $t$

and $\mathrm{G}(\mathrm{t})_{\mathrm{A}} / \mathrm{g}(\mathrm{t})_{\mathrm{A}}=$ growth rate of the GCI of Country A at time $t$

The higher the growth rate the more competitive a country is in the long run. The reason for such a scenario is that the growth rate of Country A's GCI should be increasing over time compared to that of Country B.

\section{Empirical Analysis}

This theoretical contraption is applied to the 27 low and lower-middle income Sub-Saharan African countries to determine their dynamic competitiveness. To put this analysis in to context, the economies and trade patterns of these countries are examined from 2000.

Table 1. Selected Macroeconomic Indicators (2012)

\begin{tabular}{|c|c|c|c|c|}
\hline & GDP & $\begin{array}{c}\text { Per Capita } \\
\text { GDP }\end{array}$ & Exports & Imports \\
\hline Benin & $7,557.29$ & 751.92 & - & - \\
\hline Angola & $114,147.03$ & $5,482.43$ & $68,599.83$ & $48,156.43$ \\
\hline Botswana & $14,504.34$ & $7,238.02$ & $6,453.88$ & $7,253.24$ \\
\hline Burkina Faso & $10,726.30$ & 651.65 & $2,948.43$ & $3,674.83$ \\
\hline Burundi & $2,472.38$ & 251.01 & 221.28 & 926.37 \\
\hline Cameroon & $25,321.59$ & $\quad 1,166.91$ & $7,384.62$ & $8,085.07$ \\
\hline Chad & $12,887.07$ & $1,035.26$ & $3,799.60$ & $5,035.19$ \\
\hline Cote d'Ivoire & $24,680.37$ & $1,243.99$ & - & - \\
\hline Ethiopia & $41,605.36$ & 453.57 & $5,825.14$ & $13,383.61$ \\
\hline Gambia, The & 907.43 & 506.60 & 259.21 & 460.39 \\
\hline Ghana & $40,710.78$ & $1,604.91$ & $18,666.55$ & $22,890.31$ \\
\hline Kenya & $40,697.16$ & 942.54 & $11,109.91$ & $18,108.02$ \\
\hline Lesotho & $2,447.57$ & $\quad 1,193.04$ & $1,138.68$ & $2,643.96$ \\
\hline Madagascar & $9,975.12$ & 447.44 & - & - \\
\hline Malawi & $4,263.79$ & 268.05 & - & - \\
\hline Mali & $10,387.72$ & 699.34 & $3,232.61$ & $3,903.15$ \\
\hline Mauritania & $4,199.05$ & $1,106.14$ & $2,436.42$ & $3,957.64$ \\
\hline Mauritius & $10,486.04$ & $8,119.55$ & $5,743.88$ & $6,989.32$ \\
\hline Mozambique & $14,243.72$ & 565.15 & $4,243.08$ & $10,151.26$ \\
\hline Namibia & $13,072.28$ & $5,785.75$ & $5,567.99$ & $6,857.03$ \\
\hline Nigeria & $262,597.41$ & $1,555.36$ & $145,554.88$ & $59,915.95$ \\
\hline Senegal & $14,045.76$ & $1,023.29$ & $3,411.73$ & $5,944.86$ \\
\hline South Africa & $384,312.67$ & $7,351.76$ & $108,595.06$ & $120,314.83$ \\
\hline Tanzania & $28,242.43$ & $\quad 608.72$ & $8,347.25$ & $13,364.98$ \\
\hline Uganda & $20,032.24$ & 551.16 & $4,648.63$ & $7,779.04$ \\
\hline Zambia & $20,590.28$ & $1,462.89$ & $9,549.48$ & $8,888.96$ \\
\hline Zimbabwe & $9,802.36$ & 714.23 & $4,343.72$ & $7,456.01$ \\
\hline Total & $1,144,915.56$ & & 432,081.84 & $386,140.44$ \\
\hline Average & & $1,954.84$ & & \\
\hline Maximum & $384,312.67$ & $8,119.55$ & $145,554.88$ & $120,314.83$ \\
\hline Minimum & 907.43 & 251.01 & 259.21 & 460.39 \\
\hline
\end{tabular}

Source: World Bank's World Development Index Database

In 2012, the 27 African countries in this study have a combined GDP of at least USD 1.1 trillion, an average GDP Per Capita of at least USD 1,955, combined exports of at least USD 432 billion and imports of at least USD 386 billion (See Table 1). These numbers unfortunately masks the huge disparity between the countries. South Africa's GDP of USD 384 billion is significantly more than that of the smallest (USD 907 million of Gambia). The highest GDP per capita of USD 8,119 was earned by Mauritius and the least (USD 251) by Burundi.

For the 24 countries that reported their exports and imports in the year, the largest (USD 145 billion) was made by Nigeria and the least (USD 221 million) by Burundi while South Africa imported the most (USD 120 billion) and The Gambia imported the least (USD 460 million). 
It can be argue that one of the main reasons why countries are preoccupied with improving their competitiveness is to enable them produce for exports. In some cases, this is achieved through Foreign Directed Investments that are attracted to extract or produce some natural resources for exports.

For all the 27 countries, exports have been increasing steadily since 2000, except for a-seven countries (Ghana, Angola, Burkina Faso, Malawi, Nigeria, Tanzania and Zambia) whose exports in the last 2 years increased faster than the previous two 5-years averages (see Table 2). Ghana's average is the most noticeable, increasing from USD 2.8 billion between 2000 and 2004 to USD 6 billion between 2005 and 2009 and to USD 15 billion between 2010 and 2012.

With regards their trade balances, an interesting picture is observable. Between 2000 and 2005, five countries (Note vi) had positive trade balances, meaning that they exported more than they imported. However the composition of the group changed even though the number of counties remained the same. Chad and Zambia replaced Mauritius and South Africa. From 2010 however, this number decreased to only three countries as Cote d'Ivoire, Chad and Botswana dropped from the list and registered trade deficits, meaning that they imported more than they exported. The trade pattern of these countries during this period shows that for all the countries, their exports are increasing but imports are increasing at a faster pace, except for Angola and Nigeria which registered trade surpluses throughout the period. For all these and other developing economies in Africa, the need to improve their competitiveness over time and keep it growing at an increasing rate (to exhibit dynamic competitiveness) is of strategic importance for their economic growth and development.

Table 2. Exports and Trade Balances (2000-2012)

\begin{tabular}{|c|c|c|c|c|c|c|}
\hline \multirow[t]{2}{*}{ Country } & \multicolumn{3}{|c|}{ Average Exports } & \multicolumn{3}{|c|}{ Trade balance $(2000-2012)$} \\
\hline & $2000-$ & $2005-$ & $2010-2012$ & $2000-2004$ & $2005-2009$ & 2010-2012 \\
\hline Benin & 668.04 & $1,047.46$ & $1,041.93$ & (253.47) & $(470.22)$ & (749.76) \\
\hline Angola & $9,387.91$ & $42,227.07$ & $62,574.61$ & $1,600.30$ & $13,691.42$ & $19,685.58$ \\
\hline Botswana & $3,323.98$ & $5,205.43$ & $6,051.00$ & 704.13 & 835.55 & (900.17) \\
\hline Burkina & 341.12 & 757.65 & $2,238.90$ & (494.51) & $(1,061.25)$ & (740.00) \\
\hline Burundi & 50.56 & 110.82 & 207.45 & (111.45) & $(448.38)$ & $(661.80)$ \\
\hline Cameroon & $2,984.82$ & $5,649.78$ & $6,878.03$ & (21.34) & (257.12) & (719.28) \\
\hline Chad & 732.60 & $3,661.66$ & $4,212.11$ & (754.80) & 123.17 & (624.26) \\
\hline Cote d'Ivoire & $5,636.84$ & $9,463.45$ & NA & $1,291.80$ & $1,494.33$ & NA \\
\hline Ethiopia & $1,115.89$ & $2,477.65$ & $4,850.91$ & $(1,182.14)$ & $(3,990.10)$ & $(5,771.20)$ \\
\hline Gambia, The & 171.71 & 222.36 & 247.36 & (41.46) & (120.73) & (180.91) \\
\hline Ghana & $2,811.85$ & $5,975.02$ & $15,201.90$ & $(1,160.40)$ & $(3,770.07)$ & $(3,905.24)$ \\
\hline Kenya & $3,373.44$ & $6,906.65$ & $9,949.39$ & $(1,039.81)$ & $(3,033.54)$ & $(5,543.04)$ \\
\hline Lesotho & 472.32 & 792.48 & $1,096.78$ & (707.68) & $(1,034.60)$ & $(1,487.84)$ \\
\hline Madagascar & $1,179.73$ & $2,046.64$ & $2,341.57$ & (371.65) & $(1,650.11)$ & $(1,132.02)$ \\
\hline Malawi & 556.77 & 969.29 & $1,624.45$ & (306.47) & (715.96) & $(698.70)$ \\
\hline Mali & 995.88 & $1,958.68$ & $2,828.10$ & (415.66) & (731.43) & $(1,009.75)$ \\
\hline Mauritania & 389.86 & $1,410.08$ & $2,422.57$ & (350.72) & (627.89) & (809.63) \\
\hline Mauritius & $3,098.97$ & $4,341.62$ & $5,618.83$ & 61.76 & (786.60) & $(1,265.46)$ \\
\hline Mozambique & $1,183.83$ & $2,703.77$ & $3,666.97$ & & & \\
\hline & & & & (779.70) & $(1,058.90)$ & $(3,758.61)$ \\
\hline Namibia & $1,874.83$ & $3,894.39$ & $5,333.01$ & (208.23) & (230.17) & $(1,083.08)$ \\
\hline Nigeria & $23,746.20$ & $57,900.49$ & $121,396.85$ & $7,464.19$ & $16,170.02$ & $49,800.85$ \\
\hline Senegal & $1,647.27$ & $2,847.36$ & $3,420.55$ & (655.29) & $(2,236.38)$ & $(2,302.55)$ \\
\hline South Africa & $42,819.32$ & $82,320.19$ & $108,551.22$ & & & \\
\hline & & & & $3,252.92$ & $(5,246.89)$ & $(4,973.68)$ \\
\hline Tanzania & $1,942.32$ & $4,085.74$ & $7,379.98$ & (539.00) & $(2,270.63)$ & $(4,017.12)$ \\
\hline Uganda & 750.98 & $2,377.45$ & $3,753.75$ & (791.45) & $(1,299.10)$ & $(2,688.59)$ \\
\hline Zambia & $1,246.49$ & $4,197.04$ & $8,654.92$ & (443.43) & 206.49 & $1,438.22$ \\
\hline Zimbabwe & $2,159.58$ & $1,903.36$ & $4,218.55$ & (129.54) & (920.34) & $(3,041.60)$ \\
\hline
\end{tabular}

Source: World Bank's World Development Index Database

The empirical analysis on dynamic competitiveness, mentioned above, is done firstly on the individual countries and then on a regional level by averaging their growth rates. Data from the World Economic Forum (WEF) Global Competitiveness Report's dataset for the period 2006/07 - 2012/2013 was used to determine the behaviour of the GCI of the countries in question.

The foregoing is complemented with an analysis of the growth of production and trade costs using the World Bank Doing Business dataset. As explained above, the proxy for production is the sum of the cost of starting a business, the 
minimum paid-in capital required, the cost of securing construction permits and the cost of installing electricity, all measured as percentage of income per capita. As for the cost of trade across borders, the proxy is the sum of the cost of importing and exporting a container across borders. The countries are chosen on the basis of the completeness of their data. Those for which very little data points are collected in both datasets, such as Liberia and Guinea, were dropped from the study. The coverage of countries for both datasets increases progressively and, as a result, some data points are missing for some countries. They are replaced with the average of the reported years (see Annex Table 1).

The results of the country-level analysis show that of the 27 Sub-Saharan African countries, Lesotho, Malawi, South Africa, Botswana, Ghana and Namibia have positive GCI growth rates (see Table 3) and they therefore exhibit dynamic competitiveness. It means that even as they improve their static competitiveness (increasing GCI over the period) they were also improving the growth rate of this increase. As for the rest, especially Cote d'Ivoire, Cameroon, Madagascar and Zambia, even though their indices are increasing (improving their static competitiveness) the growth rates of the indices are increasing but at decreasing rates. This means that the countries are not enjoying dynamic competitiveness.

Table 3. Growth Rates of Average GCI, Average Production and Trade Costs

\begin{tabular}{|c|c|c|c|}
\hline Entity & $\begin{array}{l}\text { Growth of } \\
\text { Production } \\
\text { Costs }\end{array}$ & $\begin{array}{l}\text { Growth } \\
\text { of Trade } \\
\text { Costs }\end{array}$ & $\begin{array}{l}\text { Average } \\
\text { Growth } \\
\text { Rate of GCI }\end{array}$ \\
\hline Benin & 0.03 & -0.01 & -0.01 \\
\hline Bots wana & 0.04 & -0.01 & 0.00 \\
\hline Burkina Faso & 0.02 & 0.00 & 0.00 \\
\hline Burundi & 0.09 & -0.01 & 0.00 \\
\hline Cameroon & 0.01 & -0.01 & -0.01 \\
\hline Chad & 0.03 & -0.01 & -0.01 \\
\hline Côte d'Ivoire & 0.01 & -0.01 & -0.02 \\
\hline Ethiopia & 0.10 & 0.00 & -0.01 \\
\hline Gambia, The & 0.07 & 0.00 & -0.01 \\
\hline Ghana & 0.10 & -0.01 & 0.00 \\
\hline Kenya & 0.01 & -0.01 & 0.00 \\
\hline Lesotho & 0.01 & -0.01 & 0.02 \\
\hline Madagascar & 0.00 & 0.00 & 0.00 \\
\hline Malawi & 0.03 & -0.02 & 0.00 \\
\hline Mali & 0.02 & -0.01 & -0.01 \\
\hline Mauritania & 0.01 & 0.00 & 0.00 \\
\hline Mauritius & 0.02 & 0.00 & -0.01 \\
\hline Mozambique & 0.02 & -0.01 & 0.00 \\
\hline Namibia & 0.02 & -0.01 & 0.01 \\
\hline Nigeria & 0.05 & -0.01 & 0.00 \\
\hline Senegal & 0.01 & 0.00 & 0.00 \\
\hline South Africa & 0.01 & -0.01 & 0.01 \\
\hline Tanzania & 0.03 & 0.02 & 0.00 \\
\hline Uganda & 0.03 & 0.00 & -0.01 \\
\hline Zambia & 0.06 & -0.01 & -0.03 \\
\hline Zimbabwe & 0.12 & 0.00 & 0.00 \\
\hline
\end{tabular}

With respect to production costs as identified above, the results show that all the countries registered positive growth rates; the highest increases were registered by Zimbabwe, Ethiopia and Burundi and the lowest by Cote d'Ivoire, Lesotho, Cameroun and South Africa. This means that production costs have been increasing in all the sample countries. With respect to trade across borders, most of the countries experienced a decline in cost over the period except for Tanzania, Uganda, Mauritius and Senegal and to a very small extent, Ethiopia. The largest decline in trade costs occurred in Kenya, followed by South Africa and then Malawi and Lesotho.

When the data is aggregated for a regional picture, the analysis shows that the GCI of the SSA countries have been increasing over the six-year period (positive trend): however, the growth rates of the average of these indices have been declining albeit slowly (declining trend) (see Annex Table 2). This means that, even though they are enjoying static competitiveness, they are not enjoying dynamic competitiveness. When the behaviour of production and trade costs of these countries are examined over the period, it shows that while production costs have been increasing at an increasing rate, trade costs have been increasing at a decreasing rate (see Annex Table 3). This phenomenon of increasing production and declining trade -across-border costs is not unique to African countries. When the results are compared to those of five Asian (Note vii) and four Commonwealth of Independent States (CIS) (Note viii) countries, the same 
pattern is observed as Asian production and trade costs decline by far. (See Figure 1).

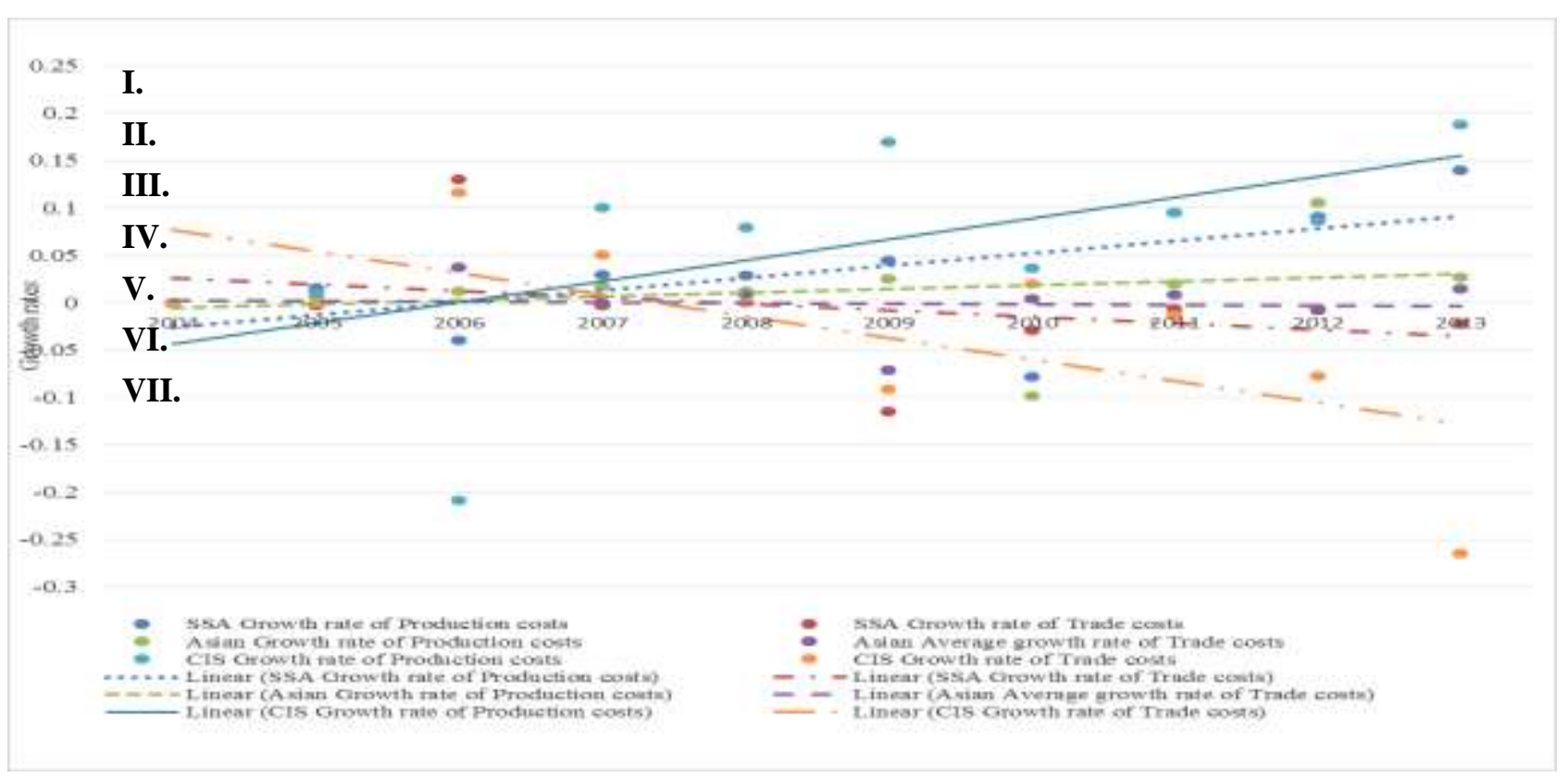

Figure 1. Trends for Growth of Production and Trade Costs

\section{Conclusions}

The study shows that the selected SSA countries are improving their competitiveness; however, this is being done at decreasing rates over the period for all but six of the 27 sample countries. Even though they are improving their competitiveness, they are not registering dynamic competitiveness as measured by the growth of GCI. The study also finds that dynamic competitiveness is enjoyed mainly by countries in the Southern African region (4 of the top 5) as Lesotho registered the highest and that production costs are increasing in all countries over the period but the cost of trade across borders is declining in all but a few countries. Despite the challenges of enjoying dynamic competitiveness, the comprehensiveness of the GCI offers policy makers a number of entry points to formulate policies that could positively impact on the competitiveness of their countries. In view of this, theoretically a country, with the right policy interventions, could transition from a state of non-competitiveness in an area to one of competitiveness. It will have to ensure that its competitiveness is improving at an increasing rate.

\section{Acknowledgements}

The comments received on various versions of the paper from the following colleagues are highly appreciated: Thierno Diallo; Abdulatef Bello; Abdallah Kiliaki; Musa Sillah; Ahmad S. Hariri; Mohammed Alwosabi; Mamoud Kamara and Elwaleed Hammour. Editorial assistance from Momodou Lamin Yaffa is also highly appreciated.

\section{References}

African Development Bank (2011). The Middle of the Pyramid: Dynamics of the Middle Class in Africa. Tunis: African Development Bank.

Amsden, A.H. (1989). Asia's Next Giant. Oxford, UK: Oxford University Press.

Biggs, T., Miller, M., Otto, C., \& Tyler, G. (1996). Africa Can Compete! Export Opportunities and Challenges for Garments and Home Products in the European Market. World Bank Discussion Papers No 300, (Washington DC): World Bank. http://dx.doi.org/10.596/0-8213-3439-5.

Cockburn, J., Siggel, E., Coulibaly, M., \& Vezina, S. (1998). Measuring Competitiveness and its Sources - The Case of Mali's Manufacturing Sector. EAGER project, Washington DC: USAID.

Elbadawi, I. (1998). Real Exchange Rate Policy and Non-Traditional Exports in Developing Countries, a product of a WIDER project on Growth, External Sector and the Role of Non-Traditional Exports in Sub-Saharan Africa.. Presented at UNECA/WIDER conference, March, Addis Ababa

Fielding, D., \& Shield, K. (2000). Is the Franc Zone and Optimal Currency Area? Journal of Economic Literature.

Farrugia, N. (2002). Constructing and Index of International Competitiveness for Malta. Bank of Valetta Review, No. 26, Autumn 2002.

Greene, W. H. (1993). Econometric Analysis (2nd ed.). New Jersey, NJ: Prentice Hall. 
International Monetary Fund. (2011). World Economic and Financial Surveys, Regional Economic Outlook. Sub-Saharan Africa: Recovery and New Risks. Washington DC: IMF.

Ji L., \& Seater, J. (2010). Schumpeterian Growth, Trade and Dynamic comparative Advantage. North Carolina, US: North Carolina State University.

Odhiambo M., Kristjanson, P., \& Kashangaki, J. (1996). Comparative Cost of production Analysis in East AfricaImplications for Competitiveness and Comparative Advantage. USAID SD Publications, Technical Paper No 32. Washington DC: USAID.

Ostry, S. (1991). Lessons from the Triad. In International Competitiveness: Interaction between the public and Private Sectors, ed. Ifran Ul Haque. Economic Development Institute Seminar Series. Washington, D.C.: World Bank.

Parades C. (1984). Nominal Exchange Rate Regimes, The Real Exchange Rate and Export Performance in Latin America. Brookings Institute Unpublished mimeo, Washington DC: Brookings Institute.

Porter M. E. (1990). The Competitive Advantage of Nations. London: Macmillan.

Redding, S. (1999). Dynamic Comparative Advantage and the Welfare Effects of Trade. Oxford Economic Papers 51. Oxford, UK: Oxford University Press. http://dx.doi.org/10.1093/oep/51.1.15.

Rodrik, D. (1994). Getting Interventions Right: How South Korea and Taiwan grew Rich. NBER Working Paper Series No 4964. Boston: NBER.

Tyson, L. D. (1993). Who's Bashing Whom: Trade Conflict in High-Technology Industries. Washington, D.C.: Institute for International Economics.

Ul Haque, I., Bell, M., Dahlman,C., Lall, S., \& Pavitt, K. (1995). Trade, Technology, and International Competitiveness. Economic Development Institute. Washington, D.C.: World Bank.

UNCTAD (1996). Developing Countries and the Uruguay Round. Geneva: United Nations Conference on Trade and Development.

UNIDO (2009). Changing patterns in Industrial Performance. A UNIDO Competitive Industrial Performance Perspective. Implications for Industrial Development Working paper 05/2009. Geneva: UNIDO.

Verbeek, M. (2000). A Guide to Modern Econometrics. New York: John Wiley and Sons, Limited.

Wood, A., \& Mayer, J. (1998). Africa's Export Structure in Comparative Perspective. UNCTAD/GDS/MDPB/Misc 4, GE 98-5I704. Geneva: UNCTAD

World Bank. (2009). Clusters of Competitiveness. A Practical Guide and Policy Implications for Developing Cluster Initiatives. Washington DC: World Bank.

World Bank. (2011). Africa's Future and the World Bank's Support to it. Washington DC: World Bank.

World Bank. (2013). Doing Business 2013 - Smarter Regulations for Small and Medium-Size Enterprises. Washington DC: World Bank.

World Bank. (2014). World Development Indicators. Retrieved January 2014 from http://databank.worldbank.org/ddp/home/do.

World Economic Forum. (2013). Global Competitiveness Index Data. Retrieved November 2013 from http://www.weforum.org/issues/competitiveness-0/gci2012-data-platform/. Geneva: World Economic Forum.

World Economic Forum. (2012). Global Competitiveness Reports. Geneva: World Economic Forum.

\section{Notes}

Note $^{\mathrm{i}}$. The POSCO case is that of the Korean Pohang Iron and Steel Company Ltd. (POSCO) is contained in Amsden (1989). This paper cites a study in which the World Bank, in the 1960s, expressed the view that an integrated iron and steel mill in Korea was a premature proposition without economic feasibility. The World Bank argued that Korea's lack of the required raw materials coupled with its small domestic market militate against her enjoying any comparative advantage in this industry. Nonetheless, in 1973 the Korean government went ahead and set up the mill with various forms of direct assistance to the company such as subsidized capital as well as indirect assistance in the form of infrastructure projects central to the company's development. In just over a decade the company became one of the producers of lowest-cost steel worldwide and by 1985, the unit cost of production in Korea was less than that in Japan and the USA.

Note ${ }^{\text {ii. }}$ In their PRSPs and National Development Plans. 
Note ${ }^{\text {iii }}$. Benin, Botswana, Burkina Faso, Burundi, Cameroon, Chad, Côte d'Ivoire, Ethiopia, Gambia, Ghana, Kenya, Lesotho, Madagascar, Malawi, Mali, Mauritania, Mauritius, Mozambique, Namibia, Nigeria, Senegal, South Africa, Tanzania, Uganda, Zambia and Zimbabwe.

Note $^{\text {iv }}$. The DRC is calculated as a ratio of the value of primary or non-tradable factors of production to the value added of tradable factors.

Note $^{\mathrm{v}}$. Starting a business, securing construction permits, installing electricity, registering property, securing credit, protecting investors, paying taxes, trading across borders, enforcing contracts, and overcoming insolvency.

Note $^{\text {vi }}$. Angola, Botswana, Mauritius, Nigeria and South Africa.

Note $^{\text {vii }}$. Bangladesh, Indonesia, Malaysia, Nepal and the Philippines

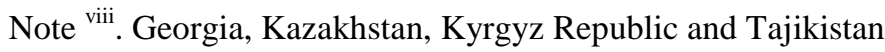

Annex Table 1 GCI for select countries

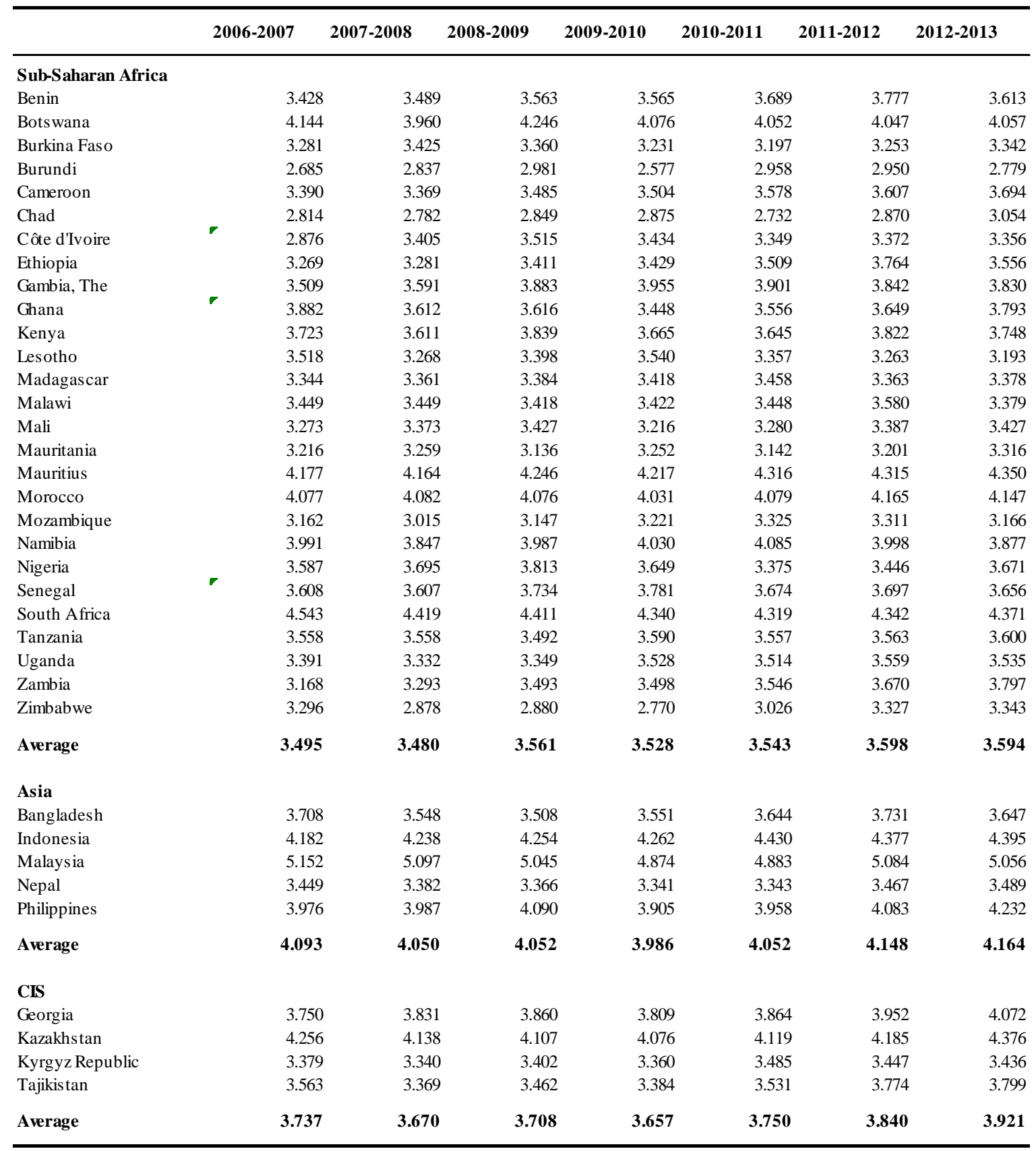

Source: World Economic Forum dataset from

http://www.weforum.org/is sues/competitiveness-0/gci2012-data-platform/

Missing data are replaced by simples averages of the years before and after. 
Annex Table 2 - GCI Growth Rates

\begin{tabular}{|c|c|c|c|c|c|c|}
\hline & \multicolumn{2}{|l|}{ SSA } & \multicolumn{2}{|c|}{ Asian Countries } & \multicolumn{2}{|c|}{ CIS Countries } \\
\hline & $\begin{array}{c}\text { Average } \\
\text { Annual } \\
\text { Growth Rate }\end{array}$ & $\begin{array}{c}\text { Average } \\
\text { GCI }\end{array}$ & $\begin{array}{c}\text { Average } \\
\text { Annual } \\
\text { Growth Rate }\end{array}$ & $\begin{array}{c}\text { Average } \\
\text { GCI }\end{array}$ & $\begin{array}{c}\text { Average } \\
\text { Annual } \\
\text { Growth Rate }\end{array}$ & $\begin{array}{c}\text { Average } \\
\text { GCI }\end{array}$ \\
\hline 2006 & & 3.344 & & 4.093 & & 3.737 \\
\hline 2007 & 0.0045 & 3.329 & 0.05969 & 4.050 & 0.019170 & 3.670 \\
\hline 2008 & -0.0221 & 3.410 & -0.00228 & 4.052 & -0.011206 & 3.708 \\
\hline 2009 & 0.0104 & 3.379 & 0.07595 & 3.986 & 0.014111 & 3.657 \\
\hline 2010 & -0.0040 & 3.392 & -0.07958 & 4.052 & -0.025633 & 3.750 \\
\hline 2011 & -0.0147 & 3.443 & -0.11703 & 4.148 & -0.022800 & 3.840 \\
\hline 2012 & 0.0016 & 3.440 & -0.01711 & 4.164 & -0.019122 & 3.921 \\
\hline
\end{tabular}

Source: Authors' computations using World Economic Forum Dataset

Annex table 3 - Average Production and Exports cost and their growth rates

\begin{tabular}{|c|c|c|c|c|c|c|c|c|c|c|c|c|}
\hline & \multicolumn{4}{|c|}{ SSA countries } & \multicolumn{4}{|c|}{ Asian countries } & \multicolumn{4}{|c|}{ CIS countries } \\
\hline & $\begin{array}{l}\text { Growth rate } \\
\text { of Production } \\
\text { costs }\end{array}$ & $\begin{array}{l}\text { Growth } \\
\text { rate of } \\
\text { Trade } \\
\text { costs }\end{array}$ & Trade cost & $\begin{array}{l}\text { Production } \\
\text { cost }\end{array}$ & $\begin{array}{l}\text { Growth } \\
\text { rate of } \\
\text { Productio } \\
\text { n costs }\end{array}$ & $\begin{array}{l}\text { Average } \\
\text { growth } \\
\text { rate of } \\
\text { Trade }\end{array}$ & $\begin{array}{c}\text { Average } \\
\text { Trade cost }\end{array}$ & $\begin{array}{c}\text { Average } \\
\text { Productio } \\
\text { n cost }\end{array}$ & $\begin{array}{l}\text { Growth } \\
\text { rate of } \\
\text { Productio } \\
n \text { costs }\end{array}$ & $\begin{array}{l}\text { Growth } \\
\text { rate of } \\
\text { Trade } \\
\text { costs }\end{array}$ & Trade cost & $\begin{array}{c}\text { Productio } \\
\text { n cost }\end{array}$ \\
\hline 2004 & 0.00 & 0.00 & 4035.91 & 7819.21 & 0.00 & 0.00 & 1893.50 & 2229.97 & 0.00 & 0.00 & 6104.84 & 1816.77 \\
\hline 2005 & 0.02 & 0.00 & 4049.16 & 7674.86 & 0.00 & 0.00 & 1893.50 & 2225.39 & 0.01 & 0.00 & 6104.84 & 1809.06 \\
\hline 2007 & 0.03 & 0.00 & 3584.70 & 7986.79 & 0.02 & 0.00 & 1809.40 & 2189.36 & 0.10 & 0.05 & 5192.50 & 2221.85 \\
\hline 2008 & 0.03 & 0.01 & 3626.78 & 7726.94 & 0.01 & 0.01 & 1783.80 & 2172.50 & 0.08 & 0.00 & 5192.50 & 2045.17 \\
\hline 2009 & 0.04 & -0.11 & 4084.59 & 7490.30 & 0.03 & -0.07 & 1930.60 & 2148.40 & 0.17 & -0.09 & 5732.50 & 1757.64 \\
\hline 2010 & -0.08 & -0.03 & 4250.15 & 8576.91 & -0.10 & 0.00 & 1915.60 & 2470.48 & 0.04 & 0.02 & 5682.50 & 1646.65 \\
\hline 2011 & 0.10 & -0.01 & 4345.22 & 7758.26 & 0.02 & 0.01 & 1968.80 & 2355.10 & 0.10 & -0.01 & 5723.75 & 1459.85 \\
\hline 2012 & 0.09 & -0.01 & 4395.93 & 6979.92 & 0.11 & -0.01 & 1987.80 & 2125.72 & 0.09 & -0.08 & 6137.50 & 1456.00 \\
\hline 2013 & 0.14 & -0.02 & 4507.63 & 5947.20 & 0.03 & 0.01 & 1985.80 & 2049.00 & 0.19 & -0.27 & 9852.50 & 1284.18 \\
\hline
\end{tabular}

Source: Authors' computation using WB Doing Business Dataset

\section{$(\mathrm{cc}) \mathrm{EY}$}

This work is licensed under a Creative Commons Attribution 3.0 License. 